\title{
Nauka Przyroda Technologie
}

Dział: Nauki o Żywności i Żywieniu

Copyright @Wydawnictwo Uniwersytetu Przyrodniczego w Poznaniu

MAGDALENA CZŁAPKA-MATYASIK ${ }^{1}$, MARZENA GRDEŃ²

${ }^{1}$ Katedra Higieny Żywienia Człowieka

Uniwersytet Przyrodniczy w Poznaniu

${ }^{2}$ Katedra Technologii Żywienia Człowieka

Uniwersytet Przyrodniczy w Poznaniu

\section{ANALIZA DOKLADNOŚCI POMIARÓW ZAWARTOŚCI TŁUSZCZU METODAMI SPEKTROFOTOMETRII, IMPEDANCJI BIOELEKTRYCZNEJ \\ I TECHNIKI ANTROPOMETRYCZNEJ \\ W PORÓWNANIU Z PLETYZMOGRAFIĄ POWIETRZNĄ U TRÓJBOISTÓW SILOWYCH}

\author{
A COMPARATIVE ANALYSIS OF THE ACCURACY OF BODY FAT \\ MEASUREMENTS USING SPECTROPHOTOMETRY, BIOELECTRICAL \\ IMPEDANCE AND ANTHROPOMETRIC TECHNIQUE VS. AIR DISPLACEMENT \\ PLETHYSMOGRAPHY IN A GROUP OF POWERLIFTERS
}

\begin{abstract}
Abstrakt
Wstęp. Analiza składu ciała sportowców jest szczególnie ważna w aspekcie planowania żywienia i obciążeń treningowych. Szczególnie w sportach siłowych powtarzalność i precyzja pomiarów odgrywają istotną rolę w przypadku okołotreningowych zmian masy i składu ciała. Precyzyjne monitorowanie tych zmian właściwie dobraną metodą pozwala na przewidywanie skutków nieodpowiedniej diety czy obciążeń treningowych. Celem pracy było porównanie dokładności pomiarów zawartości tłuszczu (\%Fat) określonej metodami spektrofotometrii (NIR), impedancji bioelektrycznej (BIA) i techniką antropometryczną (SF) w porównaniu z pletyzmografią powietrzną (BP) jako metodą referencyjną w grupie aktywnych sportowo mężczyzn uprawiających trójbój siłowy.

Material i metody. Badania wykonano jednoczasowo w grupie 49 mężczyzn (19-26 lat) uprawiających trójbój siłowy klasyczny. Zawartość tłuszczu zmierzono urządzeniem typu Bod Pod (metoda BP), aparatem FUTREX 6100A/ZL (metoda NIR), analizatorem Tanita MC 780 MA (metoda BIA) oraz cyrklem typu Harpenden (grubość fałdów tłuszczowo-skórnych, technika SF).

Wyniki. W grupie ogółem współczynnik dokładności pomiaru \%Fat wynosił w stosunku do metody referencyjnej: $100 \% \mathrm{w}$ przypadku metody BIA, $94 \% \mathrm{w}$ przypadku metody SF i $74 \%$ w przypadku metody NIR. W grupie osób o zawartości tłuszczu w ciele $\leq 20 \%$ (L-Fat-P) i $>20 \%$
\end{abstract}


Człapka-Matyasik, M., Grdeń, M. (2017). Analiza dokładności pomiarów zawartości tłuszczu metodami spektrofotometrii, impedancji bioelektrycznej i techniki antropometrycznej w porównaniu z pletyzmografią powietrzną u trójboistów siłowych. Nauka Przyr. Technol., 11, 3, 223-233. http://dx.doi.org/10.17306/J.NPT.00182

(H-Fat-P) współczynniki dokładności pomiaru wynosiły odpowiednio: 117 vs. 86\% (BIA), 105 vs. $82 \%$ (SF), 84 vs. $63 \%$ (NIR). Współczynniki korelacji pomiędzy metodami testowanymi a metodą referencyjną w grupie ogółem wynosiły 0,70 (SF), 0,61 (BIA), 0,43 (NIR), wszystkie były istotne. W grupie L-Fat-P istotną korelację wykazano między metodami BP i SF $(r=0,52)$, a w grupie H-Fat-P między metodami BP i BIA $(\mathrm{r}=0,53)$. Różnica względna w grupie ogółem oraz L-Fat-P i H-Fat-P wynosiła, odpowiednio, między metodą BP i NIR: $-20,7 \%$ oraz $-9,2 \%$ vs. $-37,1 \%$, metodą BIA: $8,9 \%$ oraz $23,6 \%$ vs. $-14,2 \%$, techniką SF: $-0,6 \%$ oraz $9,8 \%$ vs. $-17,1 \%$.

Wnioski. Uzyskane rezultaty wskazały na potrzebę starannego doboru technik analizy składu ciała osób uprawiających sporty siłowe. Największą dokładność pomiaru \%Fat wykazano w przypadku techniki antropometrycznej, umiarkowane przeszacowanie - w przypadku metody impedancji bioelektrycznej, a znaczące niedoszacowanie - w przypadku metody spektrofotometrycznej. Dokładność pomiarów zależała od zawartości tłuszczu w ciele. W przyszłości konieczne są badania wśród osób uprawiających sporty wytrzymałościowe oraz wśród nieaktywnych sportowo.

Słowa kluczowe: trójbój siłowy, impedancja bioelektryczna, spektrofotometria, pletyzmografia powietrzna, antropometria

\section{Wstęp}

Analizę komponentów składu ciała, w tym zawartości tłuszczu (\%Fat), wykorzystuje się w ocenie stanu odżywienia osób zdrowych i odchudzających się. Pomiar \%Fat odgrywa szczególną rolę w sporcie, zwłaszcza w dyscyplinach siłowych, takich jak trójbój siłowy, ponieważ intensywny trening wpływa na skład ciała, efektywność oraz wydolność zawodników (Lovera i Keogh, 2015). Precyzyjny i często powtarzany pomiar \%Fat w tej grupie zawodników jest szczególnie ważny $\mathrm{w}$ aspekcie planowania żywienia i obciążeń treningowych.

Dostępnych jest wiele metod pomiaru zawartości thuszczu w ciele, a uzyskiwane rezultaty są obarczone ograniczeniami związanymi z kosztami wykonywania, warunkami pomiaru oraz biologicznymi różnicami międzyosobniczymi. Metodą uznawaną za referencyjną jest pletyzmografia powietrzna (BP) (Biaggi i in., 1999), ale wysoki koszt specjalistycznej aparatury ogranicza możliwość powszechnego i częstego wykonywania pomiarów. Wykorzystanie innych, dostępniejszych i tańszych metod może stanowić alternatywę dla oceny zawartości tłuszczu. Problemem pozostaje dokładność pomiaru uzyskanego metodą alternatywną w porównaniu $\mathrm{z}$ referencyjną, a dodatkowym aspektem, w jakim należy rozpatrywać dokładność pomiaru, jest stopień otłuszczenia ciała zawodników.

Dobrą dokładność pomiaru zawartości tłuszczu z wykorzystaniem impedancji bioelektrycznej (BIA) oraz technik antropometrycznych (SF) wykazano u osób dorosłych zdrowych, z chorobami nerek oraz cukrzycą (Alicandro i in., 2015; Anderson, 2007; Collins i McCarthy, 2003; Fields i in., 2002; Flakoll i in., 2004; Levenhagen i in., 1999; Ostojic, 2006). Dużą zgodność pomiaru zawartości tłuszczu metodami BP, BIA oraz SF potwierdzono w badaniach z udziałem koszykarzy i rugbistów (Goosey-Tolfrey i in., 2016). Niewiele jest danych porównujących dostępne metody pomiaru zawartości tłuszczu wśród przedstawicieli sportów siłowych. Jedne z nielicznych badań w tej grupie sportowców wykazały małą zgodność metod BIA oraz promieniowania rentgenowskiego (DEXA) i sugerowały konieczność opracowania specjalnych algorytmów dla spor- 
Człapka-Matyasik, M., Grdeń, M. (2017). Analiza dokładności pomiarów zawartości tłuszczu metodami spektrofotometrii, impedancji bioelektrycznej i techniki antropometrycznej w porównaniu z pletyzmografią powietrzną u trójboistów siłowych. Nauka Przyr. Technol., 11, 3, 223-233. http://dx.doi.org/10.17306/J.NPT.00182

towców (Company i Ball, 2010). W piśmiennictwie brak jest informacji na temat dokładności pomiaru zawartości tłuszczu metodami: spektrofotometryczną (NIR), BIA oraz SF w porównaniu z metodą referencyjną u sportowców dyscyplin siłowych.

W pracy analizowano dokładność pomiaru zawartości tłuszczu metodami NIR, BIA i SF w porównaniu z BP jako metodą referencyjną z uwzględnieniem różnic w składzie ciała trójboistów siłowych.

\section{Badana grupa i metody}

Badania wykonano w grupie 49 zdrowych mężczyzn (19-26 lat) regularnie uprawiających trójbój siłowy. Początkowo, bazując na liczbie osób uprawiających trójbój siłowy, określono minimalną liczebność próby niezbędną do wnioskowania statystycznego na poziomie ufności $\mathrm{p} \leq 0,05$, z mocą statystyczną $10 \%$. Po podziale na grupy L-Fat-P i H-Fat-P sprawdzono minimalną liczebność próby, szacując ją dla oznaczeń czterema wykorzystywanymi w pracy metodami. Dla poszczególnych metod uzyskano liczebności: 2 (BP), 28 (NIR), 48 (BIA), 16 (SF).

Mężczyzn rekrutowano spośród członków Sekcji Trójboju Siłowego Klasycznego z województwa wielkopolskiego. Kryteria włączenia do badań były następujące: płeć męska, uprawianie trójboju co najmniej rok przed badaniem, udział w co najmniej trzech treningach o łącznym czasie trwania co najmniej 7,5 h na tydzień. Mężczyźni wyrazili pisemną zgodę na udział w badaniu, a protokół badań uzyskał akceptację lokalnej komisji etycznej w Uniwersytecie Medycznym im. Karola Marcinkowskiego w Poznaniu (nr 150/16).

Pomiaru zawartości tłuszczu w ciele dokonano tego samego dnia czterema metodami: pletyzmografii powietrznej (BP), spektrofotometrii (NIR), impedancji bioelektrycznej (BIA) oraz technik antropometrycznych (SF), przy czym za referencyjną przejęto metodę BP. Na podstawie zawartości tłuszczu określonej metodą referencyjną, mężczyzn podzielono na dwie podgrupy: L-Fat-P (low fat) $-\leq 20 \%$ thuszczu oraz H-Fat-P (high fat) $->20 \%$ tłuszczu, zgodnie z rekomendacjami: American College of Sports Medicine, American Council on Exercise oraz Katcha i in. (2011).

Pomiarów masy oraz wysokości ciała dokonano za pomocą wagi cyfrowej z wzrostomierzem teleskopowym (Tanita WB 3000), w pozycji stojącej. Obwód talii i bioder zmierzono z użyciem nieelastycznej taśmy antropometrycznej zgodnie z międzynarodowymi standardami (Stewart i in., 2011). Obliczono wskaźnik BMI i wskaźnik talia-do-wzrostu (WHtR). Pomiar metodą pletyzmografii powietrznej wykonano urządzeniem typu Bod Pod firmy COSMED zgodnie $z$ procedurą opisaną przez Fieldsa $\mathrm{i}$ in. (2002). Badani przystępowali do badania na czczo, w godzinach porannych, w czepkach i slipach kąpielowych. Każdy pomiar powtórzono dwu- lub trzykrotnie. Jednoczasowo pomiar \%Fat metodą NIR wykonano aparatem FUTREX 6100A/ZL, zgodnie z procedurą zalecaną przez Fthenakisa i in. (2012). Pomiar wykonywano w połowie mięśnia dwugłowego ramienia, swobodnie spoczywającej kończyny wiodącej. Do pomiaru zawartości tłuszczu metodą BIA wykorzystano analizator typu MC 780 MA - Tanita, zgodnie z procedurą opisaną przez Jebba i in. (2000). Podczas pomiaru elektrody były umieszczone na środkowej linii wewnętrznej powierzchni oczyszczonych dłoni oraz 
Człapka-Matyasik, M., Grdeń, M. (2017). Analiza dokładności pomiarów zawartości tłuszczu metodami spektrofotometrii, impedancji bioelektrycznej i techniki antropometrycznej w porównaniu z pletyzmografią powietrzną u trójboistów siłowych. Nauka Przyr. Technol., 11, 3, 223-233. http://dx.doi.org/10.17306/J.NPT.00182

stóp. Do zbadania \%Fat techniką antropometryczną wykorzystano pomiar czterech fałdów tłuszczowo-skórnych (nad tricepsem, nad bicepsem, pod łopatką, nad grzebieniem kości biodrowej) za pomocą cyrkla typu Harpenden o sile nacisku $10 \mathrm{~g} / \mathrm{cm}^{2}$. Pomiary wykonano zgodnie ze standardami międzynarodowymi (Stewart i in., 2011). \%Fat obliczono na podstawie równania Siri (Nucara i in., 2012), gdzie gęstość ciała wyliczono zgodnie z równaniem dla mężczyzn w wieku 20-29 lat (Durnin i Womersley, 1974).

Zgodność rozkładu cech z rozkładem normalnym zbadano testem Shapiro-Wilka. W celu określenia dokładności metod NIR, BIA i SF w porównaniu z BP wyliczono współczynnik korelacji liniowej Pearsona (r), różnicę bezwzględną (AD) oraz względną (RD\%) (Gawęcki, red., 2014) i współczynnik dokładności pomiarów (AC\%) (Gawęcki i Wagner, 1984), zgodnie ze wzorami:

$$
\mathrm{AD}=\text { 'metoda testowana' - 'metoda referencyjna' }
$$

$\mathrm{RD}=($ 'metoda testowana' - 'metoda referencyjna') $\times 100$ / 'metoda referencyjna'

$\mathrm{AC}=$ (wartość średnia pomiaru metodą testowaną / wartość średnia pomiaru metodą referencyjną) $\times 100$

Metodę uznano za dokładną, gdy współczynnik dokładności pomiarów mieścił się w zakresie 95-105\% metody referencyjnej.

Analizy wykonano w grupie ogółem oraz w podgrupach L-Fat-P i H-Fat-P. Istotność różnic między grupami określono testem t Studenta. Analizę statystyczną wykonano programem STATISTICA 12 PL firmy StatSoft.

\section{Wyniki}

Wyniki badań wykonanych w grupie ogółem oraz w podgrupach L-Fat-P i H-Fat-P umieszczono $\mathrm{w}$ tabeli 1 . Zgodnie $\mathrm{z}$ tym podziałem $\mathrm{u}$ badanych $\mathrm{z}$ grupy H-Fat-P obserwowano znamiennie większe wartości obwodu talii $(p<0,05)$, WHtR $(p<0,05)$ i fałdów tłuszczowo skórnych $(\mathrm{p}<0,001)$. Średnia zawartość tłuszczu w ciele określona metodą referencyjną (BP) w grupie ogółem wyniosła 17,5\%, przy czym w grupie L-Fat-P była znamiennie mniejsza niż w H-Fat-P $(\mathrm{p}<0,001)$. Najmniejszą średnią bezwzględną zawartość \%Fat określono metodą NIR zarówno w całej grupie, jak i L-Fat-P oraz H-Fat-P. Największe wartości bezwzględne \%Fat obserwowano w przypadku metody BIA, tak w grupie ogółem, jak i w podgrupach.

W tabeli 1 przedstawiono różnice względne (RD) i bezwzględne (AD) pomiędzy metodą BP a NIR, BIA oraz SF. W całej grupie największe niedoszacowania RD $\mathrm{w}$ porównaniu $\mathrm{z}$ metodą BP wykazano w przypadku NIR. Mniejsze różnice obserwowano u badanych $z$ grupy L-Fat-P $(-9,2 \%)$, a większe w grupie H-Fat-P $(-37,1 \%)$. Mniejsze różnice $\mathrm{RD} \mathrm{w}$ porównaniu $\mathrm{z}$ metodą referencyjną notowano w przypadku BIA (ogółem: 8,9\%, L-Fat-P: 23,6\%, H-Fat-P: -14,2\%). Najmniejsze różnice RD w porównaniu $\mathrm{z}$ metodą BP notowano w przypadku metody SF. W całej grupie różnica wynosiła $-0,6 \%$, a w grupach L-Fat-P i H-Fat-P odpowiednio 9,8 i-17,1\%. 
Człapka-Matyasik, M., Grdeń, M. (2017). Analiza dokładności pomiarów zawartości tłuszczu metodami spektrofotometrii, impedancji bioelektrycznej i techniki antropometrycznej w porównaniu z pletyzmografią powietrzną u trójboistów siłowych. Nauka Przyr. Technol., 11, 3, 223-233. http://dx.doi.org/10.17306/J.NPT.00182

Tabela 1. Porównanie metod oceny składu ciała w grupach o małej (L-Fat-P) i dużej (H-Fat-P) zawartości tłuszczu (średnia; 95\% CI)

\begin{tabular}{|c|c|c|c|c|}
\hline Parametr & $\begin{array}{l}\text { Ogółem } \\
\text { (49 osób) }\end{array}$ & $\begin{array}{l}\text { L-Fat-P } \\
\text { (30 osób) }\end{array}$ & $\begin{array}{l}\text { H-Fat-P } \\
\text { (19 osób) }\end{array}$ & $\begin{array}{c}\text { Istotnośćć } \\
\text { różnic } \\
\text { L-Fat-P } \\
\text { vs. } \\
\text { H-Fat-P }\end{array}$ \\
\hline Wiek (lata) & $\begin{array}{c}21,8 \\
(21,2 ; 22,3)\end{array}$ & $\begin{array}{c}21,8 \\
(21,0 ; 22,5)\end{array}$ & $\begin{array}{c}21,7 \\
(20,9 ; 22,5)\end{array}$ & ns \\
\hline Masa ciała $(\mathrm{kg})$ & $\begin{array}{c}84,8 \\
(81,4 ; 88,1)\end{array}$ & $\begin{array}{c}83,4 \\
(79,2 ; 87,5)\end{array}$ & $\begin{array}{c}87,1 \\
(80,9 ; 93,2)\end{array}$ & ns \\
\hline BMI $\left(\mathrm{kg} / \mathrm{m}^{2}\right)$ & $\begin{array}{c}25,4 \\
(24,5 ; 26,3)\end{array}$ & $\begin{array}{c}24,9 \\
(23,6 ; 26,1)\end{array}$ & $\begin{array}{c}26,1 \\
(24,9 ; 27,4)\end{array}$ & ns \\
\hline Obwód talii (cm) & $\begin{array}{c}86,0 \\
(84,0 ; 87,5)\end{array}$ & $\begin{array}{c}84,4 \\
(82,4 ; 86,4)\end{array}$ & $\begin{array}{c}88,0 \\
(84,8 ; 91,2)\end{array}$ & $*$ \\
\hline Obwód bioder $(\mathrm{cm})$ & $\begin{array}{c}93,0 \\
(91,0 ; 95,0)\end{array}$ & $\begin{array}{c}92,3 \\
(89,8 ; 94,9)\end{array}$ & $\begin{array}{c}94,9 \\
(91,4 ; 98,4)\end{array}$ & ns \\
\hline WHtR - talia-do-wzrostu & $\begin{array}{c}0,47 \\
(0,46 ; 0,48)\end{array}$ & $\begin{array}{c}0,46 \\
(0,45 ; 0,47)\end{array}$ & $\begin{array}{c}0,48 \\
(0,47 ; 0,50)\end{array}$ & $*$ \\
\hline Suma grubości fałdów thuszczowo-skórnych (mm) & $\begin{array}{c}42,5 \\
(38,6 ; 46,5)\end{array}$ & $\begin{array}{c}35,8 \\
(32,1 ; 39,5)\end{array}$ & $\begin{array}{c}53,2 \\
(47,4 ; 60,0)\end{array}$ & $* * *$ \\
\hline \multicolumn{5}{|l|}{ Zawartość thuszczu w ciele (\%) } \\
\hline metoda pletyzmografii (BP) & $\begin{array}{c}17,5 \\
(15,9 ; 19,1)\end{array}$ & $\begin{array}{c}13,7 \\
(12,5 ; 14,9)\end{array}$ & $\begin{array}{c}23,5 \\
(22,3 ; 24,8)\end{array}$ & $* * *$ \\
\hline metoda spektrofotometrii (NIR) & $\begin{array}{c}12,9 \\
(11,7 ; 14,1)\end{array}$ & $\begin{array}{c}11,5 \\
(9,9 ; 13,1)\end{array}$ & $\begin{array}{c}14,8 \\
(13,1 ; 16,5)\end{array}$ & $* * *$ \\
\hline metoda impedancji bioelektrycznej (BIA) & $\begin{array}{c}17,6 \\
(16,5 ; 18,7)\end{array}$ & $\begin{array}{c}16,0 \\
(14,8 ; 17,3)\end{array}$ & $\begin{array}{c}20,1 \\
(18,7 ; 21,6)\end{array}$ & $* * *$ \\
\hline technika antropometryczna (SF) & $\begin{array}{c}16,4 \\
(15,2 ; 17,4)\end{array}$ & $\begin{array}{c}14,4 \\
(13,3 ; 15,6)\end{array}$ & $\begin{array}{c}19,3 \\
(18,0 ; 20,7)\end{array}$ & $* * *$ \\
\hline
\end{tabular}


Człapka-Matyasik, M., Grdeń, M. (2017). Analiza dokładności pomiarów zawartości tłuszczu metodami spektrofotometrii, impedancji bioelektrycznej i techniki antropometrycznej w porównaniu z pletyzmografią powietrzną u trójboistów siłowych. Nauka Przyr. Technol., 11, 3, 223-233. http://dx.doi.org/10.17306/J.NPT.00182

Tabela $1-$ cd.

\begin{tabular}{|c|c|c|c|c|c|}
\hline \multicolumn{6}{|l|}{$\begin{array}{l}\text { Porównanie zawartości tłuszczu } \\
\text { w ciele }(\%)\end{array}$} \\
\hline \multirow[t]{4}{*}{$\begin{array}{l}\text { spektrofotometria (NIR) } \\
\text { vs. pletyzmografia (BP) }\end{array}$} & $\mathrm{AD}$ & $\begin{array}{c}-4,8 \\
(-6,5 ;-3,2)\end{array}$ & $\begin{array}{c}-2,1 \\
(-4,05 ;-0,1)\end{array}$ & $\begin{array}{c}-8,8 \\
(-10,4 ;-7,1)\end{array}$ & $* * *$ \\
\hline & RD (\%) & $\begin{array}{c}-20,7 \\
(-32,4 ;-9,0)\end{array}$ & $\begin{array}{c}-9,2 \\
(-27,8 ; 9,4)\end{array}$ & $\begin{array}{c}-37,1 \\
(-43,9 ;-30,2)\end{array}$ & $*$ \\
\hline & $\mathrm{r}$ & $0,43 * *$ & 0,11 & 0,36 & - \\
\hline & $\mathrm{AC}(\%)$ & 74 & 84 & 63 & - \\
\hline \multirow[t]{4}{*}{$\begin{array}{l}\text { impedancja bioelektryczna (BIA) } \\
\text { vs. pletyzmografia (BP) }\end{array}$} & $\mathrm{AD}$ & $\begin{array}{c}0,1 \\
(-1,2 ; 1,4)\end{array}$ & $\begin{array}{c}2,4 \\
(0,9 ; 3,9)\end{array}$ & $\begin{array}{c}-3,4 \\
(-4,7 ;-2,1)\end{array}$ & $* * *$ \\
\hline & RD (\%) & $\begin{array}{c}8,9 \\
(-1,8 ; 19,6)\end{array}$ & $\begin{array}{c}23,6 \\
(8,5 ; 38,7)\end{array}$ & $\begin{array}{c}-14,2 \\
(-19,9 ;-8,6)\end{array}$ & $* * *$ \\
\hline & $\mathrm{r}$ & $0,61 * * *$ & 0,34 & $0,53 *$ & - \\
\hline & $\mathrm{AC}(\%)$ & 100 & 117 & 86 & - \\
\hline \multirow[t]{4}{*}{$\begin{array}{l}\text { technika antropometryczna (SF) } \\
\text { vs. pletyzmografia (BP) }\end{array}$} & $\mathrm{AD}$ & $\begin{array}{c}-1,2 \\
(-2,3 ; 0,0)\end{array}$ & $\begin{array}{c}0,8 \\
(-0,4 ; 1,9)\end{array}$ & $\begin{array}{c}-4,2 \\
(-5,9 ;-2,5)\end{array}$ & $* * *$ \\
\hline & RD (\%) & $\begin{array}{c}-0,6 \\
(-8,8 ; 7,5)\end{array}$ & $\begin{array}{c}9,8 \\
(-1,5 ; 21,2)\end{array}$ & $\begin{array}{c}-17,1 \\
(-23,8 ;-10,4)\end{array}$ & $* * *$ \\
\hline & $\mathrm{r}$ & $0,70 * * *$ & $0,52 * *$ & 0,24 & - \\
\hline & $\mathrm{AC}(\%)$ & 94 & 105 & 82 & - \\
\hline
\end{tabular}

L-Fat-P - grupa o zawartości tłuszczu w ciele zmierzonej metodą pletyzmografii powietrznej $\leq 20 \%$, H-Fat-P - grupa o zawartości tłuszczu w ciele zmierzonej metodą pletyzmografii powietrznej $>20 \%$.

Poziom istotności różnic: $*-p<0,05, * *-p<0,01, * * *-p<0,001$, ns - różnice nieistotne statystycznie.

$\mathrm{AD}$ - różnica bezwzględna: 'metoda testowana' - 'metoda referencyjna'.

$\mathrm{RD}$ - różnica względna: ('metoda testowana' - 'metoda referencyjna') × 100 / 'metoda referencyjna'.

$\mathrm{r}$ - współczynnik korelacji liniowej Pearsona.

AC - współczynnik dokładności: (wartość średnia pomiaru metodą testowaną / wartość średnia pomiaru metodą referencyjną) $\times 100$.

W całej grupie występowały istotne korelacje (r) pomiędzy metodą BP a każdą z porównywanych metod (NIR: $0,43, \mathrm{p} \leq 0,01$; BIA: 0,$61 ; \mathrm{p} \leq 0,001 ; \mathrm{SF}: 0,70 ; \mathrm{p} \leq 0,001$ ). $\mathrm{W}$ grupie L-Fat-P korelacja $\mathrm{z}$ metodą referencyjną BP występowała jedynie w przypadku metody $\mathrm{SF}(0,52, \mathrm{p} \leq 0,01)$, a w grupie H-Fat-P - w przypadku BIA $(0,53, \mathrm{p} \leq 0,05)$.

Największa wartość współczynnika dokładności pomiaru (AC) w stosunku do metody referencyjnej $\mathrm{w}$ całej grupie wystąpiła w przypadku BIA (100\%). W grupach L-Fat-P i H-Fat-P wartość tego współczynnika wynosiła odpowiednio: $117 \%$ i $86 \%$. AC w przypadku metody SF w całej grupie wynosił $94 \%$. W grupie L-Fat-P było to $105 \%$, a w H-Fat-P: 82\%. Najmniejszą wartość współczynnika dokładności obserwowano w przypadku metody NIR (ogółem: 74\%, L-Fat-P: 84\%, H-Fat-P: 63\%). 
Człapka-Matyasik, M., Grdeń, M. (2017). Analiza dokładności pomiarów zawartości tłuszczu metodami spektrofotometrii, impedancji bioelektrycznej i techniki antropometrycznej w porównaniu z pletyzmografią powietrzną u trójboistów siłowych. Nauka Przyr. Technol., 11, 3, 223-233. http://dx.doi.org/10.17306/J.NPT.00182

\section{Dyskusja}

Wykonane badania wykazały istnienie znamiennych różnic w dokładności pomiaru zawartości tłuszczu w ciele trójboistów siłowych zależnie od stopnia otłuszczenia ciała i metody pomiaru.

W całej grupie badanej występowała korelacja pomiędzy każdą z porównywanych metod a metodą referencyjną. Największa wartość współczynnika korelacji wykazano z metodą SF, następnie z BIA, a najmniejszą - z NIR. Potwierdzają to badania z 1999 roku (Levenhagen i in., 1999), w których wykazano silną korelację pomiędzy metodą BP a metodą BIA u zdrowych osób dorosłych o szerokim zakresie zawartości tłuszczu ustroju.

Po zanalizowaniu danych $\mathrm{z}$ uwzględnieniem zawartości tłuszczu w ciele $\leq 20 \%$ (L-Fat-P) okazało się, że z metodą referencyjną korelowała tylko metoda SF. W grupie osób o \%Fat $>20 \% \mathrm{z}$ metodą referencyjną korelowała jedynie metoda BIA, przy czym wartość współczynnika korelacji była istotnie mniejsza niż w badaniach Company’ego i Balla (2010) (0,61 vs. 0,81), w których nie dokonano podziału na grupy pod względem zawartości tłuszczu w ciele, co może tłumaczyć różnice uzyskane w niniejszych badaniach. W naszych badaniach nie wykazano zgodności metody NIR z metodą referencyjną niezależnie od stopnia otłuszczenia ciała. Wyniki zbliżone do uzyskanych w ramach niniejszej pracy opisano w badaniach amerykańskich (Housh i in., 2004) z udziałem wytrenowanych zapaśników, gdzie wykazano, iż metoda NIR nie jest dostosowana do pomiaru zawartości tłuszczu w grupie sportowców uprawiających dyscypliny siłowe.

Uzyskane rezultaty świadczą o tym, że metody BIA i SF są dokładne dla grup o szerokim zakresie \%Fat w ustroju, ich dokładność natomiast maleje, gdy wyniki rozpatrywane są indywidualnie. Różnice średniej \%Fat w ciele zmierzonej metodami BIA i SF nie odbiegały od uzyskanych metodą referencyjną w przypadku analizy w całej grupie. W badaniach brytyjskich (Goosey-Tolfrey i in., 2016) z udziałem wytrenowanych koszykarzy i rugbistów także wykazano brak istotnych różnic między \%Fat mierzoną metodą BP oraz SF. W L-Fat-P \%Fat mierzona metodą BIA była zawyżona, co potwierdzają badania Company'ego i Balla (2010), a w grupie H-Fat-P pomiar SF i BIA był zaniżony w stosunku do metody referencyjnej.

Największe różnice w porównaniu z metodą referencyjną wykazano w przypadku pomiaru zawartości tłuszczu techniką w bliskiej podczerwieni (NIR). Niezależnie od stopnia otłuszczenia ciała (mniejszego lub większego) były one niedoszacowane, co potwierdziły badania Housha i in. (2004) w grupie młodych zapaśników.

W całej grupie trójboistów siłowych o średniej zawartości tłuszczu w ciele $(17,5 \%)$ współczynnik dokładności pomiarów (AC) dla metody BIA wynosił 100\%. Jak sugeruje literatura (Gawęcki i Wagner, 1984), AC dla wyników uzyskanych z wykorzystaniem metody wzorcowej powinien być większy od 95 . Współczynnik pogarszał się i świadczył o przeszacowaniach u mężczyzn w grupie L-Fat-P (AC: 117\%). W grupie H-Fat-P współczynnik dokładności pomiarów świadczył o niedoszacowaniach zawartości \%Fat w ciele i wynosił $86 \%$. Bardzo dużą dokładność pomiaru \%Fat wykazano w przypadku metody SF, gdzie współczynnik w całej grupie wynosił 94\%, a w grupie L-Fat-P 105\%.

Należy zaznaczyć, że metoda jest oparta na wytrenowanych umiejętnościach manualnych doświadczonych badaczy. W niniejszych badaniach pomiary antropometryczne 
Człapka-Matyasik, M., Grdeń, M. (2017). Analiza dokładności pomiarów zawartości tłuszczu metodami spektrofotometrii, impedancji bioelektrycznej i techniki antropometrycznej w porównaniu z pletyzmografią powietrzną u trójboistów siłowych. Nauka Przyr. Technol., 11, 3, 223-233. http://dx.doi.org/10.17306/J.NPT.00182

fałdów tłuszczowo-skórnych były wykonywane przez jednego, doświadczonego badacza. Najmniejsze wartości współczynników dokładności pomiarów w przypadku wszystkich porównywanych metod w odniesieniu do metody referencyjnej określono w grupie H-Fat-P z wykorzystaniem metody NIR. Sugeruje to, że precyzyjne oznaczanie zawartości tłuszczu w ciele osób o większej \%Fat tą metodą może sprawiać największe trudności i skutkować niedoszacowaniami.

Wykonane badania wskazują na konieczność doboru metody pomiaru zawartości tłuszczu w zależności od stanu odżywienia badanego, szczególne w przypadku indywidualnego szacowania. Warto jednocześnie podkreślić, iż uzyskane wyniki wymagają potwierdzenia $\mathrm{w}$ badaniach $\mathrm{z}$ udziałem liczniejszej grupy sportowców uprawiających dyscypliny siłowe. Celowe byłoby też porównanie uzyskanych pomiarów z metodą promieniowania rentgenowskiego (DEXA), która stanowi metodę alternatywną dla pletyzmografii i daje możliwość analizy rozmieszczenia tkanki tłuszczowej w ustroju. Zaletą niniejszego opracowania jest fakt, iż pomiary wykonano $\mathrm{w}$ grupie dotychczas mało zbadanej i narażonej na duże zmiany zawartości \%Fat. Niniejsza praca wedle najlepszej wiedzy autorów jest jedyną porównującą dokładność metod NIR, BIA oraz $\mathrm{SF}$ z referencyjną BP z udziałem trójboistów siłowych.

\section{Wnioski}

1. Największą dokładność pomiaru zawartości tłuszczu w ciele trójboistów siłowych uzyskano w przypadku techniki antropometrycznej, umiarkowane przeszacowanie pomiaru - w przypadku metody impedancji elektrycznej, a znaczące niedoszacowanie pomiaru - w przypadku metody spektrofotometrycznej.

2. Dokładność pomiarów zależała od zawartości tłuszczu w ciele. U trójboistów siłowych o zawartości tłuszczu w ciele $\leq 20 \%$ stwierdzono tendencję do przeszacowania pomiaru, a zawodników z większą $->20 \%$ - zawartością tłuszczu w ciele - znaczące niedoszacowanie tej zawartości.

3. Do pomiaru zawartości tłuszczu w ciele należy rekomendować indywidualny dobór metody, dostosowanej do tej zawartości, jeśli nie istnieje możliwość użycia wysoce precyzyjnych metod pomiarowych. Metodę alternatywną dla pletyzmografii powietrznej u osób o małej zawartości tłuszczu w ciele może stanowić technika antropometryczna.

\section{Literatura}

Alicandro, G., Battezzati, A., Bianchi, M. L., Loi, S., Speziali, Ch., Bisogno, A., Colombo, C. (2015). Estimating body composition from skinfold thicknesses and bioelectrical impedance analysis in cystic fibrosis patients. J. Cyst. Fibros., 14, 6, 784-791. http://dx.doi.org/10. 1016/j.jcf.2015.07.011

Anderson, D. E. (2007). Reliability of air displacement plethysmography. J. Strength Cond. Res., 21, 1, 169-172. http://dx.doi.org/10.1519/R-19745.1

Biaggi, R. R., Vollman, M. W., Nies, M. A., Brener, C. E., Flakoll, P. J., Levenhagen, D. K., Sun, M., Karabulut, Z., Chen, K. Y. (1999). Comparison of air-displacement plethysmography 
Człapka-Matyasik, M., Grdeń, M. (2017). Analiza dokładności pomiarów zawartości tłuszczu metodami spektrofotometrii, impedancji bioelektrycznej i techniki antropometrycznej w porównaniu z pletyzmografią powietrzną u trójboistów siłowych. Nauka Przyr. Technol., 11, 3, 223-233. http://dx.doi.org/10.17306/J.NPT.00182

with hydrostatic weighing and bioelectrical impedance analysis for the assessment of body composition in healthy adults. Am. J. Clin. Nutr., 69, 5, 898-903.

Collins, A. L., McCarthy, H. D. (2003). Evaluation of factors determining the precision of body composition measurements by air displacement plethysmography. Eur. J. Clin. Nutr., 57, 6, 770-776. http://dx.doi.org/10.1038/sj.ejcn.1601609

Company, J., Ball, S. (2010). Body composition comparison: bioelectric impedance analysis with dual-energy x-ray absorptiometry in adult athletes. Meas. Phys. Educ. Exerc. Sci., 14, 3, $186-$ 201. http://dx.doi.org/10.1080/1091367X.2010.497449

Durnin, J. V., Womersley, J. (1974). Body fat assessed from total body density and its estimation from skinfold thickness: measurements on 481 men and women aged from 16 to 72 years. Br. J. Nutr., 32, 1, 77-97. http://dx.doi.org/10.1079/BJN19740060

Fields, D. A., Goran, M. I., McCrory, M. A. (2002). Body-composition assessment via air-displacement plethysmography in adults and children: a review. Am. J. Clin. Nutr., 75, 3, $453-467$.

Flakoll, P. J., Kent, P., Neyra, R., Levenhagen, D., Chen, K. Y., Ikizler, T. A. (2004). Bioelectrical impedance vs air displacement plethysmography and dual-energy X-ray absorptiometry to determine body composition in patients with end-stage renal disease. J. Parent. Enter. Nutr., 28, 1, 13-21. http://dx.doi.org/10.1177/014860710402800113

Fthenakis, Z. G., Balaska, D., Zafiropulos, V. (2012). Uncovering the FUTREX-6100XL prediction equation for the percentage body fat. J. Med. Eng. Technol., 36, 7, 351-357. http://dx.doi.org/10.3109/03091902.2012.708382

Gawęcki, J. (red.). (2014). Kwestionariusz do badania poglądów i zwyczajów żywieniowych oraz procedura opracowania danych. Warszawa: Komitet Nauki o Żywieniu Człowieka PAN. http://dx.doi.org/10.13140/2.1.3207.7125

Gawęcki, J., Wagner, W. (1984). Podstawy metodologii badań doświadczalnych w nauce o żywności i żywieniu. Warszawa: PWN.

Goosey-Tolfrey, V., Keil, M., Brooke-Wavell, K., de Groot, S. (2016). A comparison of methods for the estimation of body composition in highly trained wheelchair games players. Int. J. Sports Med., 37, 10, 799-806. http://dx.doi.org/10.1055/s-0042-104061

Housh, T. J., Johnson, G. O., Housh, D. J., Cramer, J. T., Eckerson, J. M., Stout, J. R., Rana, S. R. (2004). Accuracy of near-infrared interactance instruments and population-specific equations for estimating body composition in young wrestlers. J. Strength Cond. Res., 18, 3, 556-560. http://dx.doi.org/10.1519/1533-4287(2004)18<556:AONIIA $>2.0 . C O ; 2$

Jebb, S. A., Cole, T. J., Doman, D., Murgatroyd, P. R., Prentice, A. M. (2000). Evaluation of the novel Tanita body-fat analyser to measure body composition by comparison with a four-compartment model. Br. J. Nutr., 83, 2, 115-122. http://dx.doi.org/10.1017/S0007114 500000155

Katch, V. L., McArdle, W. D., Katch, F. I. (2011). Essentials of exercise physiology. Philadelphia: Wolters Kluwer.

Levenhagen, D. K., Borel, M. J., Welch, D. C., Piasecki, J. H., Piasecki, D. P., Chen, K. Y., Flakoll, P. J. (1999). A comparison of air displacement plethysmography with three other techniques to determine body fat in healthy adults. J. Parent. Enter. Nutr., 23, 5, 293-299. http://dx.doi.org/10.1177/0148607199023005293

Lovera, M., Keogh, J. (2015). Anthropometric profile of powerlifters: differences as a function of bodyweight class and competitive success. J. Sports Med. Phys. Fit., 55, 5, 478-487.

Nucara, A., Pietrafesa, M., Rizzo, G., Scaccianoce, G. (2012). An anthropometric analysis of seated and standing people. W: V. R. Preedy (red.), Handbook of anthropometry (s. 91-114). New York: Springer. http://dx.doi.org/10.1007/978-1-4419-1788-1

Ostojic, S. M. (2006). Estimation of body fat in athletes: skinfolds vs bioelectrical impedance. J. Sports Med. Phys. Fit., 46, 3, 442-446. 
Człapka-Matyasik, M., Grdeń, M. (2017). Analiza dokładności pomiarów zawartości tłuszczu metodami spektrofotometrii, impedancji bioelektrycznej i techniki antropometrycznej w porównaniu z pletyzmografią powietrzną u trójboistów siłowych. Nauka Przyr. Technol., 11, 3, 223-233. http://dx.doi.org/10.17306/J.NPT.00182

Stewart, A. D., Marfell-Jones, M., Olds, T., De Ridder, J. H. (2011). International standards for anthropometric assessment. Lower Hutt, New Zealand: International Society for the Advancement of Kinanthropometry, $125 \mathrm{f}$.

\title{
A COMPARATIVE ANALYSIS OF THE ACCURACY OF BODY FAT MEASUREMENTS USING SPECTROPHOTOMETRY, BIOELECTRICAL IMPEDANCE AND ANTHROPOMETRIC TECHNIQUE VS. AIR DISPLACEMENT PLETHYSMOGRAPHY IN A GROUP OF POWERLIFTERS
}

\begin{abstract}
Background. The analysis of athletes' body composition is particularly important for planning nutrition and training loads. Reproducibility and precision of measurements are particularly important in strength sports, when there are fluctuations in the body mass and composition around training. Precise monitoring of these changes with an adequate method enables prediction of the effects of inadequate diet or workload. The aim of the study was to assess body fat (\%Fat) measurements with spectrophotometry (NIR), bioelectrical impedance (BIA) and the anthropometric technique (SF) and to compare them with air plethysmography (BP) as a reference method in a group of powerlifters.

Material and methods. The study was conducted simultaneously on a group of 49 men aged 1926 years, practising classic powerlifting. The body fat content was measured with the Bod Pod (BP method), FUTREX 6100A/ZL (NIR method), Tanita MC 780 MA (BIA method), whereas skin thickness was measured with a Harpenden skinfold calliper (SF technique).

Results. The total measurement accuracy coefficient for $\%$ Fat was $100 \%$ with BIA, $94 \%$ with SF and $74 \%$ with NIR, as compared with the reference method. In the group with the body fat content $\leq 20 \%$ (L-Fat-P) and $>20 \%$ (H-Fat-P) the accuracy coefficients were respectively 117 vs. $86 \%$ (BIA), 105 vs. $82 \%$ (SF) and 84 vs. $63 \%$ (NIR). The total correlation coefficients between the methods under analysis and the reference method were significant: 0.70 (SF), 0.61 (BIA), 0.43 (NIR). In the L-Fat-P group there was a significant correlation between the BP and SF methods $(0.52)$, and in the H-Fat-P group - between the BP and BIA methods (0.53). There were relative differences in the total group, L-Fat-P and H-Fat-P between the BP and NIR methods: $-20.7 \%$ and $-9.2 \%$ vs. $-37.1 \%$, the BIA method: $8.9 \%$ and $23.6 \%$ vs. $-14.2 \%$, and the SF technique: $-0.6 \%$ and $9.8 \%$ vs. $-17.1 \%$, respectively.

Conclusions. The results indicated the need to select carefully the techniques analysing athletes' body composition. Fat percentage measurement with the anthropometric technique was the most accurate; it was moderately overestimated when the bioelectrical impedance method was applied, whereas the spectrophotometric method resulted in significant underestimation. The accuracy of the measurements depended on the body fat content. In the future it is necessary to conduct research on endurance athletes as well as people who do not practise sports.
\end{abstract}

Keywords: powerlifting, bioelectrical impedance, spectrophotometry, air plethysmography, anthropometry 
Człapka-Matyasik, M., Grdeń, M. (2017). Analiza dokładności pomiarów zawartości tłuszczu metodami spektrofotometrii, impedancji bioelektrycznej i techniki antropometrycznej w porównaniu z pletyzmografią powietrzną u trójboistów siłowych. Nauka Przyr. Technol., 11, 3, 223-233. http://dx.doi.org/10.17306/J.NPT.00182

Adres do korespondencji-Corresponding address:

Magdalena Człapka-Matyasik, Katedra Higieny Żywienia Człowieka, Uniwersytet Przyrodniczy w Poznaniu, ul. Wojska Polskiego 31/33,60-624 Poznań, Poland, e-mail: magdalena.matyasik@ up.poznan.pl

Zaakceptowano do opublikowania - Accepted for publication:

3.07.2017

Do cytowania - For citation:

Człapka-Matyasik, M., Grdeń, M. (2017). Analiza dokładności pomiarów zawartości tluszczu metodami spektrofotometrii, impedancji bioelektrycznej i techniki antropometrycznej w porównaniu z pletyzmografia powietrzna u trójboistów siłowych. Nauka Przyr. Technol., 11, 3, 223-233. http://dx.doi.org/10.17306/J.NPT.00182 